\title{
Eksplorasi Tumbuhan Obat Tradisional Desa Blata Tatin Kecamatan Kangae Kabupaten Sikka
}

\author{
Helena Lanur ${ }^{\mathrm{a}}$, dan Oktavius Yoseph Tuta Mago ${ }^{\mathrm{b}}$
}

${ }^{a}$ Fakultas Keguruan dan Ilmu Pendidikan, Universitas Nusa Nipa, Maumere, Sikka - NTT, Indonesia.

${ }^{b}$ Fakultas Keguruan dan Ilmu Pendidikan, Universitas Nusa Nipa, Maumere, Sikka - NTT, Indonesia, email: magoyotta@ gmail.com

\section{Article Info}

\section{Article history:}

Received 1 Desember 2018

Received in revised form 20 Desember 2018 Accepted 20 Desember 2018

DOI:

https://doi.org/10.32938/slk.v1i2.526

Keywords:

Blata Tatin, Eksplorasi, Tumbuhan, Obat tradisional

\begin{abstract}
Abstrak
Penelitian ini dilatarbelakangi oleh banyaknya penggunaan obat sintetis dalam mengobati berbagai macam penyakit, semakin minim penggunaan obat tradisional dan kurangnya data tentang tumbuhan obat tradisional. Tujuan dari penelitian ini adalah untuk men geksploras tumbuhan obat yang dimanfaatkan di Desa Blata Tatin, Kecamatan Kangae, Kabupaten Sikka. Sampel tumbuhan obat dikumpulkan dengan teknik survei eksploratif setelah memperoleh informasi dengan mewawancarai informan kunci dan responden di desa tersebut. Data informasi tumbuhan obat disajikan dalam bentuk tabulasi dan deskripsikan secara lengkap. Hasil penelitian menemukan 13 jenis tumbuhan obat yang digunakan di Desa Blata Tatin yaitu sambiloto (Andrographis paniculata), pisang (Musa sp.), waru (Hibiscustiliaceus L.), ubi jalar (Ipomoeabatatas), kemiri (Aleuritesmoluccana L.), kunyit (Curcumadomestica Val.), kencur (Kaempferiagalanga L.), jahe (Zingiberofficinale Rosc.), kelapa (Cocosnucifera), daun kentut (Paederiascandens Merr.), pegagan (Centellaasiatica L.), daun sirih (Piperbetle L.) dan bayam (Amaranthusspinosus L.).
\end{abstract}

\section{Pendahuluan}

Pulau Flores memiliki banyak potensi sumber daya alam yang dapat dimanfaatkan untuk kesejahteraan hidup manusia. Salah satunya adalah tumbuhtumbuhan yang berkhasiat untuk menyembuhkan berbagai jenis penyakit. Nenek moyang orang Flores sudah mampu memanfaatkan obat-obatan dari bahan tumbuhan untuk mengobati berbagai macam penyakit sejak zaman dahulu. Pengetahuan tentang khasiat tumbuhan obat ini diwariskan secara turun-temurun dari generasi ke generasi.

Penggunaan obat sintetik yang semakin meningkat dalam dua dekade terakhir ini membuat masyarakat perkotaan mulai meninggalkan pengobatan tradisional. Warisan pengetahuan nenek moyang mulai tergerus oleh modernisasi dan kekhawatiran akan hilangnya kearifan lokal bisa terjadi. Hal ini terbukti jika melihat banyak masyarakat sekarang yang kurang mengetahui kelebihan tersendiri yang dimiliki tumbuhan obat tradisional.

Pengetahuan masyarakat secara umum mengenai pemanfaatan tumbuhan obat masih rendah. Hanya sedikit orang yang mampu meracik obat tradisional, yaitu orang-orang berpengalaman atau dukun yang sudah berusia lanjut. Kebanyakan dukun merahasiakan racikan obatnya dengan alasan, diperoleh langsung dari nenek moyangnya sehingga hanya dapat diwariskan kepada anak cucunya saja. Kelemahan dari prinsip ini adalah jika tidak ada keturunannya yang mau belajar tentang meracik obat tradisional, maka ilmu tersebut akan hilang. Padahal, pengetahuan mengenai pemanfaatan tumbuhan obat harus terus dilestarikan.

Pengobatan di Desa Blata Tatin lebih banyak menggunakan obat tradisional yang alami dibandingkan dengan obat sintetik. Hal ini disebabkan karena terdapat banyak tumbuhan obat dan masih banyak orang di desa tersebut yang mampu meramu obat dari tumbuhan ini. Kearifan lokal di desa ini masih terus dipertahankan sampai saat ini, namun permasalahannya adalah minimnya data tentang jenis tumbuhan obat dan manfaatnya yang belum diketahui banyak pihak. Penelitian ini bermaksud untuk mendapatkan data spesies tumbuhan obat, organ yang digunakan, cara penggunaan tumbuhan obat tersebut, dan manfaatnya dalam pengobatan.

\section{Metode}

Penelitian ini dilakukan di Desa Blata Tatin, Kecamatan Kangae, Kabupaten Sikka pada bulan Agustus sampai September 2017. Pengumpulan data dilakukan dengan wawancara informan kunci dan responden, serta survei eksploratif untuk mengumpulkan tumbuhan obat. Wawancara bertujuan untuk mendapat informasi tentang jenis tumbuhan obat, manfaat pengobatan dan cara penggunaannya. Jenis wawancara yang digunakan adalah wawancara mendalam, semi-struktur dan wawancara bebas (Moleong, 2004).

Penentuan informan kunci dilakukan menggunakan teknik snowball sampling berdasarkan pertimbangan pada kriteria tertentu seperti tua adat, tokoh masyarakat, kepala desa atau dukun. Responden ditentukan melalui metode stratified random sampling dengan pembagian sampel berdasarkan strata umur. Strata umur yang diambil sebagai sampel adalah kelompok umur 17-29 tahun, 30-49 tahun dan 50 tahun ke atas (Sugiyono, 2011).

Identifikasi spesies tumbuhan obat dilakukan secara langsung di lapangan dengan mengacu pada buku sumber seperti Ensiklopedi tumbuhan berkhasiat obat (Raina, 2011), Tanaman Obat (Sudarsono $d k k$., 1996) dan Flora untuk Sekolah di Indonesia (Steenis, 2006)

\section{Hasil dan Pembahasan}

Eksplorasi di desa Blata Tatin menemukan 13 jenis tumbuhan obat yang digunakan masyarakat desa untuk mengobati 29 jenis penyakit. Tiga belas spesies tumbuhan obat ini berasal dari 11 famili tumbuhan, dengan rincian 3 spesies dari famili Zingiberaceae dan masing-masing 1 spesies dari famili Piperaceae, Amaranthaceae, Euphorbiaceae, Musaceae, Arecaceae, Rubiaceae, Acanthaceae, Malvaceae, Convolvulaceae, dan Apiaceae. Spesies tumbuhan obat yang digunakan di desa Blata Tatin dapat dilihat pada Tabel 1.
Tabel 1. Jenis Tumbuhan Obat di desa Blata Tatin

\begin{tabular}{cllll}
\hline No & Nama Lokal & Nama Komersil & \multicolumn{1}{c}{ Nama Ilmiah } & \multicolumn{1}{c}{ Famili } \\
\hline 1. & Guni & Kunyit & Curcuma domestica Val. & Zingiberaceae \\
2. & Hekur & Kencur & Kaempferia galanga L. & Zingiberaceae \\
3. & Le'a & Jahe & Zingiber officinale Rosc. & Zingiberaceae \\
4. & Ta'a & Sirih & Piper betle L. & Piperaceae \\
5. & Arung & Bayam & Amaranthus spinosus L. & Amaranthaceae \\
6. & Gelo & Kemiri & Aleurites moluccana L. & Euphorbiaceae \\
7. & Mu'u & Pisang & Musa sp. & Musaceae \\
8. & Kabor & Kelapa & Cocos nucifera L. & Arecaceae \\
9. & Poho & Daun kentut & Paederia scandens Merr. & Rubiaceae \\
10. & Klotong & Sambiloto & Andrographis paniculata & Acanthaceae \\
11. & Logo & Waru & Hibiscus tiliaceus L. & Malvaceae \\
12. & Tuka & Ubi jalar & Ipomoea batatas & Convolvulaceae \\
13. & Puhe beta & Pegagang & Centella asiatica L. & Apiaceae \\
\hline
\end{tabular}

Berdasarkan data dari tabel di atas, dapat digambarkan bahwa masyarakat desa Blata Tatin memiliki cukup banyak tumbuhan obat. Masyarakat desa in juga memiliki pengetahuan yang memadai, untuk meramu tumbuhan tersebut sebagai bahan dasar obat tradisional. Tiga belas jenis tumbuhan obat ini dapat ditemukan di sekitar wilayah desa Blata Tatin, karena sebagian besar tumbuhan telah dibudidaya oleh masyarakat. Sedangkan, beberapa jenis tumbuhan tumbuh liar di kebun warga.

Penggunaan bagian/organ tumbuhan obat dalam pengobatan suatu penyakit, berbeda-beda antara satu jenis tumbuhan dan jenis tumbuhan lainnya Bagian tumbuhan obat yang paling banyak digunakan adalah daun, dengan jumlah 6 spesies. Rimpang dan akar masing-masing 3 spesies, sedangkan batang, bunga, buah dan biji, masing-masing 1 spesies. Dapat dilihat lebih lengkap pada Tabel 2

Daun banyak digunakan sebagai bahan baku obat karena strukturnya yang lunak dan mempunyai kandungan air yang tinggi. Daun juga merupakan tempat akumulasi fotosintat yang diduga mengandung senyawa berkhasiat. Senyawa yang terdapat di dalam daun adalah minyak atsiri, fenol, kalium dan klorofil. Daun tumbuhan obat ini biasanya direbus, kemudian diminum atau digunakan untuk mandi. Tujuan perebusan adalah agar kandungannya dapat pindah ke dalam air. Tumbuhan yang digunakan daunnya sebagai bahan baku obat adalah sirih (Piper betle L.), sambiloto (Andrographis paniculata), daun kentu (Paederia scandens Merra), waru (Hibiscus tiliaceus L.), ubi jalar (Ipomoea batatas), dan pegagan (Centella asiatica L.).

Masyarakat juga menggunakan organ rimpang, seperti jahe, kunyit dan kencur sebagai obat. Rimpang mengandung banyak zat bermanfaat karena merupakan tempat penimbunan cadangan makanan. Jenis senyawa yang terdapat di dalam rimpang jahe antara lain seskuiterpen, gingerol, zingiberene, zingiron, oleoresin, limonene, a-sitosterol, capylic acid, capsaicin chlorogenic acid, sitral, zingiberal, felandren, 1,8 cineole, dan guanicol (Syamsuhidayat, 1991; Tim Lentera, 2004). Masyarakat desa Blata Tatin memanfaatkan kunyit sebagai obat batu dan gusi bengkak. Rimpang kunyit yang berumur lebih dari satu tahun juga dapat digunakan untuk menurunkan panas, membersihkan lambung dan menghentikan pendarahan (Said, 2003). Kencur digunakan sebagai obat sakit kepala, sakit gigi, gusi bengkak, dan mimisan. Selain itu, rimpang kencur memiliki khasiat sebagai penambah nafsu makan, ekspektoran, obat batuk, disentri, tonikum, infeksi bakteri, masuk angin, dan sakit perut (Assat, 2011) Rimpang tumbuhan obat dapat digunakan dengan cara langsung dimakan atau terlebih dahulu digerus, dipanaskan kemudian ditempelkan pada bagian tubuh yang sakit.

Pada beberapa tumbuhan obat, kandungan zat berkhasiat terdapat pada organ akar, yaitu bayam, pisang dan pegagan. Akar pegagan dapat digunakan masyarakat desa untuk meredahkan panas tinggi. Mulyani (2006) menyatakan efek farmakologi yang telah diketahui dari pegagan adalah antidemam, antidiuretikum, keratolitik dan antikeloid. Akar pisang dimanfaatkan sebagai obat sakit perut, sesak napas, asam urat dan ginjal. Penelitian Azizah (2016) menyatakan bahwa ekstrak akar pisang mampu menghambat pertumbuhan 
bakteri pathogen Candida albicans. Akar bayam digunakan untuk mengobati sakit gigi, gusi bengkak dan gangguan pernapasan.

Tabel 2. Organ Tumbuhan Obat yang Digunakan serta Cara Penggunaannya

\begin{tabular}{|c|c|c|c|c|}
\hline No. & $\begin{array}{c}\text { Organ } \\
\text { Tumbuhan }\end{array}$ & $\begin{array}{c}\text { Jenis } \\
\text { Tumbuhan } \\
\end{array}$ & $\begin{array}{c}\text { Cara } \\
\text { Penggunaan } \\
\end{array}$ & Penyakit yang Disembuhkan \\
\hline \multirow{6}{*}{1.} & \multirow{6}{*}{ Daun } & Pegagan & Direbus & Nyeri haid dan panas tinggi \\
\hline & & Sirih & Direbus & $\begin{array}{l}\text { Pembersih daerah kewanitaan, sesak } \\
\text { napas }\end{array}$ \\
\hline & & Daun kentut & Direbus & $\begin{array}{l}\text { Batuk, memperlancar kencing dan } \\
\text { nyeri haid }\end{array}$ \\
\hline & & Sambiloto & Direbus & $\begin{array}{l}\text { Kencing manis, amandel, batuk } \\
\text { rejan, darah tinggi }\end{array}$ \\
\hline & & Ubi jalar & $\begin{array}{l}\text { Digerus dan } \\
\text { dipanaskan }\end{array}$ & Keseleo \\
\hline & & Waru & $\begin{array}{l}\text { Digerus dan } \\
\text { dipanaskan }\end{array}$ & Keseleo \\
\hline \multirow{5}{*}{2.} & \multirow{5}{*}{ Rimpang } & Kencur & $\begin{array}{l}\text { Langsung } \\
\text { dimakan }\end{array}$ & $\begin{array}{l}\text { Sakit kepala, sakit gigi, gusi } \\
\text { bengkak, mimisan }\end{array}$ \\
\hline & & Kunyit & $\begin{array}{l}\text { Langsung } \\
\text { dimakan }\end{array}$ & Batuk dan gusi bengkak \\
\hline & & & $\begin{array}{l}\text { Digerus dan } \\
\text { dipanaskan }\end{array}$ & $\begin{array}{l}\text { Gusi bengkak, batuk, luka ringan, } \\
\text { bisul dan kanker }\end{array}$ \\
\hline & & Jahe & $\begin{array}{l}\text { Langsung } \\
\text { dimakan }\end{array}$ & $\begin{array}{l}\text { Sakit kepala, batuk, masuk angin, } \\
\text { gatal-gatal, sakit perut dan rematik }\end{array}$ \\
\hline & & & $\begin{array}{l}\text { Digerus dan } \\
\text { dipanaskan }\end{array}$ & Batuk dan keseleo \\
\hline \multirow{3}{*}{3.} & \multirow{3}{*}{ Akar } & Pisang & Digerus & $\begin{array}{l}\text { Sakit perut, sesak napas, asam urat } \\
\text { dan ginjal }\end{array}$ \\
\hline & & Pegagan & Digerus & Panas tinggi \\
\hline & & Bayam & $\begin{array}{l}\text { Dicampur } \\
\text { dengan } \\
\text { bahan lain }\end{array}$ & $\begin{array}{l}\text { Sakit gigi, gusi bengkak dan } \\
\text { gangguan pernapasan }\end{array}$ \\
\hline 4. & Batang & Daun kentut & $\begin{array}{l}\text { Dicampur } \\
\text { dengan } \\
\text { bahan lain }\end{array}$ & Cacingan dan rematik \\
\hline 5. & Bunga & Kelapa & Digerus & Sesak napas \\
\hline 6. & Buah & Sirih & $\begin{array}{l}\text { Langsung } \\
\text { dimakan }\end{array}$ & Sakit gigi dan gusi bengkak \\
\hline \multirow[t]{2}{*}{7.} & \multirow[t]{2}{*}{ Biji } & \multirow[t]{2}{*}{ Kemiri } & $\begin{array}{l}\text { Dicampur } \\
\text { dengan } \\
\text { bahan lain }\end{array}$ & $\begin{array}{l}\text { Panas tinggi, kejang, penyakit } \\
\text { kuning, vitalitas pria dan kanker }\end{array}$ \\
\hline & & & $\begin{array}{l}\text { Digerus dan } \\
\text { dipanaskan }\end{array}$ & Luka ringan dan gatal-gatal \\
\hline
\end{tabular}

Masyarakat desa menggunakan organ batang dari tumbuhan daun kentut untuk mengobati penyakit cacingan dan rematik. Nurcahyanti \& Wandra (2012) menyatakan bahwa beberapa manfaat daun kentut (sembukan) adalah sebagai penghilang racun (detoksifikasi), obat cacing dan peredah kejang. Khasiat yang dimiliki daun kentut ini berasal dari kandungan senyawa aktif seperti indol, alkaloid, asperulosid, asam ursolat dan metil merkaptan. Kandungan metil mercaptan inilah yang membuat daun kentut memiliki bau yang kurang sedap.

Kelapa merupakan tumbuhan yang memiliki nilai ekonomis paling tinggi. Hampir seluruh bagian tubuhnya digunakan manusia. Masyarakat desa Blata Tatin memanfaatkan bunga kelapa sebagai obat peredah sesak napas. Cara penggunaannya adalah dengan menggerus bunga kelapa, kemudian ditempelkan pada bagian dada.

Buah sirih juga memiliki manfaat sebagai obat, di samping daunnya yang telah diketahui memiliki banyak khasiat. Masyarakat desa menjadikan buah sirih dan pinang sebagai 'cemilan' wajib yang biasa dikonsumsi pada waktu upacara adat atau pengisi waktu luang. Buah sirih diyakini mampu memperkuat gigi dan menjaga kesehatan gusi. Hal ini dapat dilihat dari jumlah gigi yang masih utuh pada pengkonsumsi sirih-pinang dengan umur di atas 50 tahun.

Masyarakat desa Blata Tatin memanfaatkan biji kemiri untuk mengobati luka ringan dan gatal-gatal pada kulit. Cara penggunaannya adalah kemiri terlebih dahulu digerus, dipanaskan dan ditempelkan pada luka atau kulit yang gatal. Kemiri juga dapat dicampur dengan bahan lain untuk mengobati penyakit kuning, panas tinggi, kejang, kanker dan menjaga vitalitas pria.

\section{Simpulan}

Masyarakat desa Blata Tatin menggunakan 13 jenis tumbuhan obat yang tergolong dalam 11 famili. Tumbuhan obat dimanfaatkan untuk mengobati 29 jenis penyakit. Organ tumbuhan yang paling banyak digunakan berturut-turut adalah daun, rimpang, akar, batang, bunga, buah dan biji. Cara penggunaan tumbuhan obat sangat bervariasi, tergantung pada jenis penyakit yang disembuhkan.

\section{Pustaka}

Assat, L. 2011. Fraksinasi Senyawa Aktif Minyak Atsiri Kencur (Kaempferia galanga L.) sebagai Pelangsing Aromaterapi secara In Vivo. Tesis. Bogor: Institut Pertanian Bogor.

Azizah, N. 2016. Analisis Ekstrak Batang dan Akar Pisang Kepok (Musa paradisiaca L.) dalam Menghambat Pertumbuhan Candida albicans. Skripsi ed. Makasar: Universitas Hasanuddin.

Moleong, L.J. 2004. Metodologi Penelitian Kualitatif. Bandung: PT Remaja Rosdakarya. (2009). Metodologi penelitian kualitatif(edisi revisi).
Mulyani, E.S. 2006. Mulyani. Yogyakarta: Kanisius.

Nurcahyanti, A.D. \& Wandra, J. 2012. embukan: Kurang Sedap namun Berkhasiat Hebat. BioS-Majalah Ilmiah Semipopuler, Vol. 5 No. 2.

Raina. 2011. Ensiklopedi Tumbuhan Berkhasiat Obat. Jakarta: Salemba Medika. Said 2003. Khasiat dan Manfaat Kunyit. Jakarta: PT Sinar Widya Lestari.

Steenis, C.G.G. 2006. Flora untuk Sekolah di Indonesia. Jakarta: Pradnya Paramita.

Sudarsono, P.., Gunawan, D., Wahyuono, S., Donatus, I.. \& Drajad, M. 1996. Daftar Tumbuhan Obat. Yogyakarta: UGM.

Sugiyono. 2011. Metode Penelitian Kuantitatif Kualitatif dan R\&D. Bandung: Alfabeta.

Syamsuhidayat. 1991. Inventarisasi Tanaman Obat Indonesia - Edisi Kedua. Edisi ke 2. Jakarta: Departemen Kesehatan RI.

Tim Lentera. 2004. Khasiat \& Manfaat Jahe si Rimpang Ajaib. Jakarta: AgroMedia Pustaka. 